\title{
FAKTOR-FAKTOR YANG MEMPENGARUHI KEBERHASILAN PENERAPAN AKUNTANSI PEMERINTAH BERBASIS AKRUAL (STUDI KASUS PADA PEMERINTAH KOTA BEKASI)
}

\author{
Budiman Slamet \\ Dosen Fakultas Ekonomi Universitas Pakuan dan Widyaiswara Utama Pusdiklatwas BPKP \\ E-mail: budiman.sl1954@gmail.com
}

\begin{abstract}
This study was aimed to examine the effect of training/technical guidance on accrual-based government's financial statements against human resource competency as well as to test the head of government agencies commitment, competency of human resource, and accounting application usage against successful adoption of accrual-based government accounting. This research implemented survey explanatory approach by surveying some agencies (SKPDs) of Bekasi city government. The analytical method used is path analysis with the help of AMOS software for data processing questionnaires. The results of this study are: (1) training/technical guidance preparation of the accrual-based government's financial statements partially positive effects on human resource competency (2) head of government agencies commitment partially positive influences on the success of the accrual-based government accounting implementation (3) human resource competency partially positive influences on the success of accrual-based government accounting implementation (4) accounting applications usage partially positive influences on the success of the accrual-based government accounting implementation and (5) head of government agencies commitment, accounting applications usage, as well as human resource competency simultaneously affect positively on the success of government's adoption of accrual-based accounting.
\end{abstract}

Keywords: Head of Government Agencies Commitment, Training/Technical Guidance on AccrualBased Government's Financial Statements, Competency of Human Resource, Accounting Applications Usage, Implementation of Accrual-Based Accounting for Government

\section{PENDAHULUAN}

Kebijakan-kebijakan pemerintah pusat terutama kebijakan dalam pengelolaan keuangan negara haruslah melibatkan pemerintah daerah. Sebab, kinerja dan pengelolaan keuangan daerah saat ini menduduki posisi penting dalam strategi pemberdayaan pemerintah daerah, terlebih lagi dalam mewujudkan pelaksanaan otonomi daerah dan mewujudkan desentralisasi yang luas, nyata, dan bertanggungjawab.

Dari total belanja APBN 2017 sebesar $2.070,5$ triliun, diantaranya sebesar 760,5 triliun (atau sekitar 36,73\%) ditransfer dan dikelola untuk pemerintah daerah berupa: dana bagi hasil, dana alokasi umum, dana alokasi khusus, dana otonomi khusus dan alokasi dana desa. Tuntutan terhadap pengelolaan keuangan rakyat dengan baik merupakan isu utama yang harus dilakukan pemerintah daerah dalam mewujudkan tujuan pemerintahan yang bersih (clean goverment). Pengelolaan keuangan daerah yang baik adalah kemampuan mengendalikan kebijakan keuangan daerah secara ekonomis, efisien, transparan, dan akuntabel.

Menurut ketentuan dalam ketiga undangundang di bidang keuangan negara, yakni: Undang-Undang Nomor 17 Tahun 2003 tentang Keuangan Negara, Undang-Undang Nomor 1 Tahun 2004 tentang Perbendaharaan Negara, dan Undang-Undang Nomor 15 Tahun 2004 tentang Pemeriksaan atas Pengelolaan Tanggung Jawab Keuangan Negara, sistem akuntansi pemerintah Indonesia menganut basis akrual. Kemudian dengan ditetapkannya Peraturan Pemerintah Nomor 71 Tahun 2010 sebagai pengganti Peraturan Pemerintah Nomor 24 Tahun 2005, standar akuntansi 
pemerintahan Indonesia telah menganut basis akrual.

Pasal 36 ayat (1) UU Nomor 17 Tahun 2003 menyebutkan bahwa "pengakuan dan pengukuran pendapatan dan belanja berbasis akrual dilaksanakan selambat-lambatnya dalam lima tahun sejak tahun 2003. Selama pengakuan dan pengukuran pendapatan dan belanja berbasis akrual belum dilaksanakan, digunakan pengakuan dan pengukuran berbasis kas".

Mengingat pentingnya pengukuran pendapatan dan belanja berbasis akrual, maka ketentuan tersebut dinyatakan kembali dalam pasal 70 ayat (2) UU Nomor 1 Tahun 2004 bahwa "pengakuan dan pengukuran pendapatan dan belanja berbasis akrual dilaksanakan selambat-lambatnya pada tahun anggaran 2008 dan selama pengakuan dan pengukuran pendapatan dan belanja berbasis akrual belum dilaksanakan, digunakan pengakuan dan pengukuran berbasis kas".

Penulis tertarik mengambil topik ini, karena terdapat ketentuan perundangundangan mengharuskan pemerintah segera menerapkan akuntansi pemerintahan berbasis akrual. Namun, nampaknya penerapan basis akrual di banyak pemerintah daerah belum sepenuhnya siap untuk melaksanakannya. Artinya, meski mulai tahun anggaran 2015 pemerintah pusat/pemerintah daerah wajib menyusun laporan keuangan berbasis akrual, namun sebagian besar masih harus "dibimbing/dibantu" oleh BPKP. Penulis menduga hal ini disebabkan kurangnya: komitmen pimpinan instansi pemerintah, sumber daya manusia yang mengerjakan penatausahaan keuangan, dan kemungkinan lainnya, misalnya belum adanya aplikasi akuntansi yang sempurna pada pemerintah daerah.

Adapun tujuan yang ingin dicapai dalam penelitian ini adalah:

1. Mengetahui ada/tidaknya pengaruh diklat/bimtek penyusunan laporan keuangan pemerintah berbasis akrual terhadap peningkatan kompetensi sumber daya manusia.
2. Mengetahui ada/tidaknya pengaruh komitmen pimpinan instansi pemerintah terhadap keberhasilan penerapan akuntansi pemerintah berbasis akrual.

3. Mengetahui ada/tidaknya pengaruh kompetensi sumber daya manusia terhadap keberhasilan penerapan akuntansi pemerintah berbasis akrual.

4. Mengetahui ada/tidaknya pengaruh penggunaan aplikasi akuntansi terhadap keberhasilan penerapan akuntansi pemerintah berbasis akrual.

5. Mengetahui ada/tidaknya pengaruh komitmen pimpinan instansi pemerintah, kompetensi sumber daya manusia, dan penggunaan aplikasi akuntansi secara bersama-sama dan simultan terhadap keberhasilan penerapan akuntansi pemerintah berbasis akrual.

\section{KAJIAN LITERATUR DAN PENGEMBANGAN HIPOTESIS}

\section{Komitmen Pimpinan Instansi}

Dalam teori total quality management, keberhasilan kepemimpinan ditunjukkan dengan adanya interaksi positif antara pimpinan puncak, manager divisi dan karyawan. Interaksi menunjukkan kerjasama satu sama lainnya dalam menangani masalah organisasi. Para manager divisi berperan penting mengkomunikasikan aktivitas organisasi yang akan dilaksanakan kepada sesama manager dan kepada bawahan. Demikian juga pimpinan puncak harus menempatkan sumber daya yang memadai guna menjamin keberhasilan dan kelanjutan penerapan perbaikan (kaizen). Masaaki Imai (1999) mengungkapkan dalam setiap kesempatan, manajemen puncak harus menyampaikan pesannya tentang komitmen yang diyakini dan harus menempatkan sumber daya yang memadai guna menjamin keberhasilan dan kelanjutan penerapan perbaikan (kaizen).

Konsep pimpinan instansi pemerintah didefinisikan sebagai tanggung jawab atau kemauan yang tinggi untuk menjalankan suatu tugas dan pekerjaan dengan niat 
yang sungguh-sungguh. Komitmen dibutuhkan untuk membangun hubungan antar pekerja dengan atasannya untuk menciptakan iklim kerja yang kondusif dan memberikan tanggung jawab yang jelas.

Konsep variabel komitmen pimpinan instansi pemerintah, diambil dari berbagai teori, yaitu: kriteria manager proyek yang baik menurut Timothy R. Barry, kemudian teori the five pratices and ten commitments of exemplary leadership oleh James $M$. Kouzes dan Barry Z. Posner, yang meliputi dimensi: menginspirasi visi bersama, menantang proses, memberikan keteladanan, meneguhkan hati, dan mengaktifkan yang lain untuk bertindak.

Bila dikaitkan dengan pendapat Choi \& Behling (1997) mengenai komitmen pimpinan puncak, bahwa tanggung jawab penyusunan laporan keuangan Pemerintah Kota Bekasi tergantung pada banyak pihak. Pimpinan puncak SKPD/SKPKD tidak bekerja sendiri tetapi harus bekerja sama dengan orang lain atau bawahannya. Kerjasama harus ditunjukkan melalui keterlibatan pimpinan puncak dalam melaksanakan tugas pokoknya, yaitu dengan mengarahkan, mempengaruhi, mendorong bawahannya ke arah berbagai tujuan dalam organisasi termasuk dalam pelaksanaan penyusunan laporan keuangan pemerintah daerah yang berbasis akrual.

\section{Kompetensi Sumber Daya Manusia}

Kompetensi memiliki pengertian yang sama dengan capability (kemampuan). Seseorang yang kompeten adalah yang memiliki kemampuan, pengetahuan dan keahlian untuk melakukan sesuatu secara efisien dan efektif.

Berdasarkan Peraturan Pemerintah Nomor 101 Tahun 2000 tentang Diklat Jabatan PNS, bahwa kompetensi adalah kemampuan dan karakteristik yang dimiliki oleh seorang PNS berupa pengetahuan, keterampilan dan sikap perilaku yang diperlukan dalam melaksanakan tugas jabatannya.

Kompetensi Sumber Daya Manusia (SDM) secara umum berarti kemampuan dan karakteristik yang dimiliki seorang PNS berupa pengetahuan (knowledge), keterampilan (skill), sikap dan perilaku (behavioral and attitude), yang diperlukan dalam pelaksanaan tugas jabatannya (Mustopadidjaja, 2002). Disinilah kompetensi sumber daya manusia PNS menjadi satu karakteristik yang mendasari individu atau seseorang mencapai kinerja yang tinggi dalam pekerjaannya. Karakteristik ini muncul dalam bentuk pengetahuan, keterampilan, dan perilaku untuk menciptakan aparatur yang memiliki semangat pengabdian yang tinggi dalam melayani masyarakat yang selalu bertindak hemat, efisien, rasional, transparan, dan akuntabel. Jadi, pelayanan publik merupakan pemberdayaan masyarakat yang pada gilirannya dapat menggerakan roda perekonomian menuju kesejahteraan.

Konsep variabel kompetensi sumber daya manusia, diambil dari berbagai teori kompetensi SDM, yaitu: teori kompetensi dari Aiswort dan sebagainya. Menurut Spencer and Spencer (1994) kompetensi sumber daya manusia meliputi dimensi: pengetahuan yang berkaitan dengan pekerjaan (kognitif), keterampilan individu (psikomotorik), dan sikap kerja (behavioral and attitude). Kompetensi sumber daya manusia di atas, yang mempengaruhi secara langsung dan tidak langsung terhadap kinerjanya.

Dengan demikian dapat disintesakan bahwa kompetensi SDM dapat mempercepat penyusunan laporan keuangan berbasis akrual pada pemerintah Kota Bekasi.

\section{Penggunaan Aplikasi Akuntansi}

Salah satu hal yang mempengaruhi kinerja instansi pemerintah daerah adalah pemanfaatan teknologi informasi. Perkembangan teknologi informasi direspons oleh organisasi dengan mendesain sistem informasi berbasis teknologi komputer atau website. Sistem informasi yang didukung teknologi informasi dapat memberikan nilai tambah bagi SKPD/SKPKD jika didesain menjadi sistem informasi yang efektif.

Konsep variabel penggunaan aplikasi akuntansi, diambil dari berbagai teori teknologi informasi. Faktor-faktor yang 
dapat dipertimbangkan dalam menentukan sistem informasi akuntansi menurut Laudon (Husein dan Wibowo, 2000, h.317) adalah ketelitian dan keamanan. Teknologi informasi (TI) berkaitan dengan pelayanan, hal tersebut dikarenakan salah satu dimensi dari kualitas pelayanan adalah kecepatan pelayanan (Parasuramanet al., 1988 dalam Mardjiono 2009), yaitu dimensi tersebut dapat dikaitkan dengan teknologi informasi. Dengan adanya TI, maka pelayanan yang diberikan khususnya pada organisasi jasa, akan semakin cepat dan akurat.

Dengan demikian dapat disintesakan bahwa pemanfaatan teknologi informasi yang tepat (teliti, cepat dan aman), serta didukung oleh keahlian personil yang mengoperasikannya dapat meningkatkan kinerja pemerintah Kota Bekasi maupun kinerja individu yang mengoperasikannya.

\section{Diklat/Bimtek Penyusunan Laporan Keuangan Berbasis Akrual}

Pendidikan dan pelatihan adalah suatu usaha pengembangan sumber daya manusia untuk meningkatkan kemampuan teknis, teoritis, konseptual dan moral karyawan sesuai dengan kebutuhan pekerjaan atau jabatan (Hasibuan, 2003). Program pengembangan karyawan hendaknya disusun secara cermat dan fokus kepada keterampilan yang dibutuhkan perusahaan/instansi pemerintah saat ini dan masa yang akan datang. Pengembangan karyawan sangatlah penting sebagai tuntutan dari pekerjaan atau jabatan. Menurut Dessler (1997), pelatihan merupakan suatu proses mengajarkan kepada karyawan baru atau yang ada sekarang, berupa keterampilan dasar yang dibutuhkan untuk menjalankan pekerjaan. Pelatihan berfokus kepada keterampilan yang dibutuhkan untuk menjalankan pekerjaan karyawan sekarang, pengembangan karyawan dan manajemen yang bersifat jangka panjang. Arahnya adalah mengembangkan karyawan sekarang dan mendatang untuk tugas-tugas masa depan atau memecahkan masalah organisasi.

$$
\text { Konsep variabel diklat/bimtek }
$$

penyusunan laporan keuangan berbasis akrual yang diselenggarakan oleh BPKP, diambil dari berbagai teori manajemen sumber daya manusia. Konsep tersebut berdampak pada peningkatan kompetensi peserta diklat/bimtek, baik menyangkut ranah kognitif, psikomotorik, attitude, motivation, maupun responsibilty. Variabel diklat/ bimtek penyusunan laporan keuangan berbasis akrual.

\section{Keberhasilan Penerapan Akuntansi Pemerintah Berbasis Akrual}

Dalam teori ilmu komunikasi keberhasilan diartikan sebagai umpan balik. Artinya komunikasi yang dilakukan oleh komunikator (istilah komunikan merujuk pada pengertian teori komunikasi, yang meliputi komunikator, yang berbicara - dan komunikate, yang mendengarkan) dinilai berhasil jika efektif mempengaruhi perilaku komunikate, dan atau komunikate telah mengalami proses decoding, penyandian balik berupa umpan balik dirinya bagi sang komunikator. Indikator keberhasilan ini terlihat, misalnya: Saya menulis (komunikator), kamu membaca sampai selesai (komunikate) lantas kamu menilai ada yang salah dalam tulisan ini. Tak lama kemudian kamu mengangkat telepon, dan mengatakan bahwa tulisan saya ada yang keliru ( terjadi umpan balik) ${ }^{1}$.

Konsep keberhasilan ini akan berbeda halnya jika mengikuti istilah empirisme alam (katakan fisika, misalnya). Suatu teori baru dinyatakan valid, jika sudah dapat dibuktikan dengan proses penginderaan (empiric). Artinya, konsep apapun baru dipandang sebatas hipotesis jika belum dibuktikan secara nyata. Jika terbukti benar, maka hal itu adalah berhasil. Demikian pula jika kita berbicara tentang arti keberhasilan-keberhasilan lain yang berangkat dari konsep yang berbeda, tentunya akan mengalami diversifikasi yang beragam pula.

Secara sintesa, keberhasilan Kota Bekasi dalam menerapkan sistem akuntansi pemerintah berbasis akrual, dibuktikan dalam

1http :// Rumah Makna/2012/10/9, Alike Mulyadi K, Arti Keberhasilan, Jatinangor 2004 
Pertanggungjawaban Pelaksanaan APBD Tahun Anggaran 2015 (Perda Kota Bekasi Nomor 04 Tahun 2016 Tanggal 23 September 2016) telah mengimplementasikan tujuh komponen laporan keuangan sebagaimana diatur dalam Peraturan Pemerintah Nomor 71 tahun 2010, yaitu: 1). LRA; 2). Neraca; 3). LAK; 4). LO; 5). LPSAL; 6). LPE; 7). CaLK.

\section{Kerangka Pemikiran}

Kerangka pemikiran di bawah ini menunjukan bahwa apakah:

1. Variabel diklat/bimtek penyusunan laporan keuangan $\left(\mathrm{X}_{1}\right)$ secara individual berpengaruh positif dan signifikan terhadap variabel kompetensi SDM,

2. Variabel komitmen pimpinan instansi pemerintah $\left(\mathrm{X}_{2}\right)$, variabel kompetensi
SDM $\left(X_{3} / Y_{1}\right)$, serta variabel penggunaan aplikasi akuntansi $\left(\mathrm{X}_{4}\right)$, secara individual dan secara simultan/bersama-sama berpengaruh positif dan signifikan terhadap variabel keberhasilan penerapan akuntansi pemerintah Indonesia berbasis akrual $\left(\mathrm{Y}_{2}\right)$.

Dalam hal ini variabel terikat (dependent variable) adalah keberhasilan penerapan akuntansi Pemerintah Indonesia berbasis akrual $\left(Y_{2}\right)$. Variabel intervening adalah komptensi sumber daya manusia $\left(Y_{1}\right)$, sedangkan untuk variabel-variabel bebas (independent variables) adalah: diklat/bimtek penyusunan laporan keuangan $\left(\mathrm{X}_{1}\right)$, komitmen pimpinan instansi pemerintah $\left(X_{2}\right)$, kompetensi sumber daya manusia $\left(X_{3}\right)$, serta penggunaan aplikasi akuntansi $\left(\mathrm{X}_{4}\right)$.

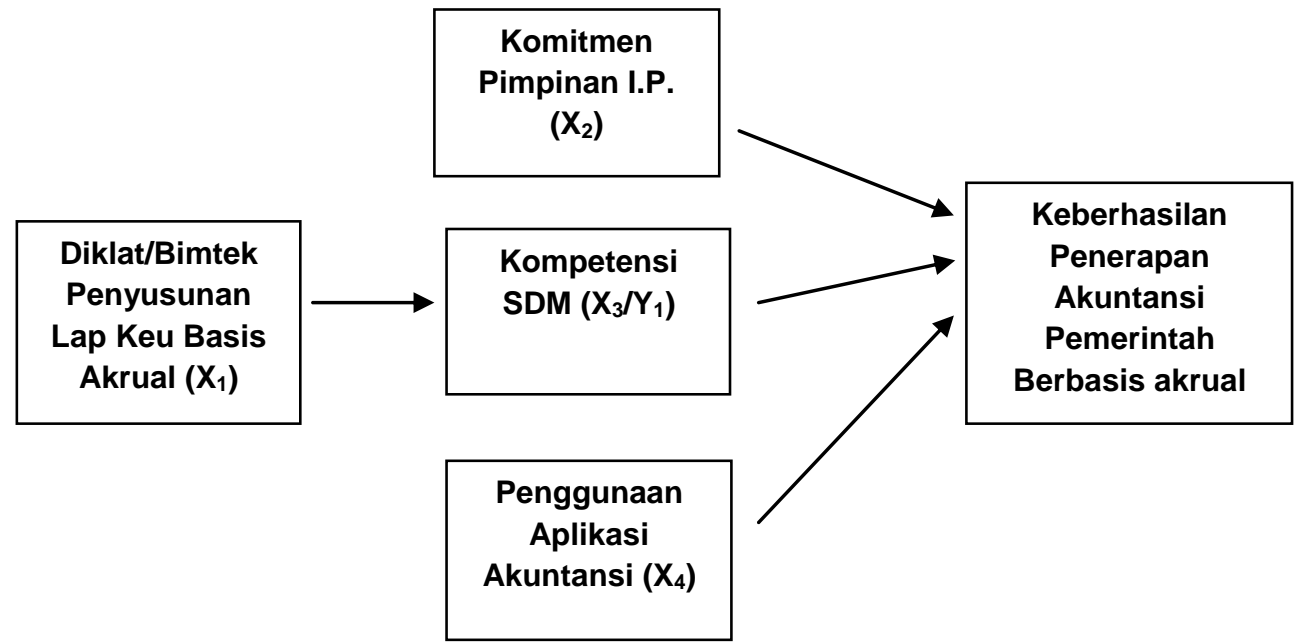

Gambar 2.1 Kerangka Pemikiran

\section{Hipotesis}

Hipotesis yang akan dikemukan untuk penyusunan penelitian ini adalah:

H1: Aspek diklat/bimtek penyusunan laporan keuangan dengan sistem SIMDA secara parsial berpengaruh positif dan signifikan terhadap kompetensi SDM.

$\mathrm{H} 2$ : Aspek komitmen pimpinan instansi secara parsial berpengaruh positif dan signifikan terhadap keberhasilan penerapan akuntansi pemerintah berbasis akrual.
H3: Aspek kompetensi SDM secara parsial berpengaruh positif dan signifikan terhadap keberhasilan penerapan akuntansi pemerintah berbasis akrual.

H4: Aspek penggunaan aplikasi akuntansi secara parsial berpengaruh positif dan signifikan terhadap keberhasilan penerapan akuntansi pemerintah berbasis akrual.

H5: Semua aspek komitmen pimpinan, kompetensi SDM dan penggunaan aplikasi akuntansi secara simultan berpengaruh positif dan signifikan 
terhadap keberhasilan penerapan akuntansi pemerintah berbasis akrual.

\section{METODOLOGI PENELITIAN}

Metode Penarikan Sampel

Populasi merupakan wilayah generalisasi yang terdiri atas objek/subjek yang mempunyai kualitas tertentu yang ditetapkan (Sugiyono 2009:80). Populasi yang hendak diteliti dalam penelitian ini adalah seluruh SKPD pada Pemerintah Kota Bekasi berjumlah 44 SKPD, dengan responden penelitian tiap SKPD adalah:

a. Kepala SKPD atau yang mewakili Kepala SKPD,

b. Pejabat Penatausahaan Keuangan SKPD (PPK-SKPD),

c. Staf PPK-SKPD sebagai pelaksana penyusunan laporan keuangan.

Dengan demikian populasinya sebanyak = $44 \times 3=132$ responden.
Sampel menurut Sugiyono (2009:61) adalah sebagian dari jumlah dan karakteristik yang dimiliki oleh populasi. Penentuan sampel adalah proses memilih sejumlah elemen dari populasi target, sehingga berdasarkan analisis terhadap sampel yang memiliki karakteristik tertentu, akan dapat ditarik kesimpulan umum (generalisasi) terhadap populasi. Berdasarkan tujuan survei, maka populasi target dapat ditentukan. Pemilihan sampel dilakukan dengan menggunakan convenience sampling.

Jumlah sampel yang representative dilakukan berdasarkan pada tingkat pengembalian kuesioner yang disebarkan kepada peserta diklat, di samping menggunakan rumus Slovin sebagai berikut:

$$
n=\frac{N}{N \cdot d^{2}+1}
$$

dimana:

$$
\begin{aligned}
& \mathrm{n}=\text { ukuran sampel } \\
& \mathrm{N}=\text { ukuran populasi } \\
& \mathrm{d}=\text { galat pendugaan }
\end{aligned}
$$

Artinya, seandainya hanya sebagian responden yang mengembalikan kuesioner, kemudian galat pendugaan (d) sebesar $5 \%$, maka sampel yang dipakai untuk membuktikan hipotesis, cukup diwakili oleh sekitar 100 responden.

\section{Teknik Pengumpulan Data}

Pengumpulan data dilakukan dengan metode kuesioner. Metode kuesioner adalah pengumpulan data yang dilakukan dengan mengajukan pertanyaan tertulis dalam suatu daftar pertanyaan yang ditujukan untuk memperoleh data yang lebih otentik.

Untuk mengukur pendapat responden terhadap variabel bebas/independen, digunakan skala likert, yaitu: skala yang berisi lima tingkat preferensi jawaban dengan pilihan sebagai berikut:

Angka 1 = Sangat Tidak Setuju (STS)

Angka 2 = Tidak Setutu (TS)

Angka 3 = Cukup Setuju (CS)

Angka 4 = Setuju (S)

Angka 5 = Sangat Setuju (SS)

Data dikumpulkan melalui metode angket, yaitu menyebarkan kuesioner yang akan diisi atau dijawab oleh auditor peserta diklat investigatif, maupun oleh atasan peserta diklat tersebut. Pengukuran variabel-variabel menggunakan baik pertanyaan tertutup maupun terbuka. 


\section{Metode Pengolahan / Analisis Data}

Adapun uji yang digunakan dalam penelitian ini adalah dengan menggunakan:

1. Uji validitas, yaitu suatu ukuran yang menunjukkan tingkat keabsahan dan kevalidan suatu alat ukur atau instrumen penelitian.

2. Uji realibilitas, indeks yang menunjukan sejauh mana suatu pengukuran tanpa bias (bebas kesalahan) dan karena itu menjamin pengukuran yang konsisten lintas waktu dan lintas beragam item dalam instrumen (Sekaran, 2010).

3. Analisa regresi, digunakan untuk mengetahui besarnya pengaruh diklat/bimtek penyusunan laporan keuangan terhadap peningkatan kompetensi SDM.

4. Analisa regresi berganda, digunakan untuk mengetahui besarnya pengaruh: komitmen pimpinan instansi, kompetensi SDM, penggunaan aplikasi akuntansi terhadap keberhasilan penerapan akuntansi pemerintah berbasis akrual.

5. Pengujian secara parsial (uji t), digunakan untuk menguji hipotesis secara parsial guna menunjukkan pengaruh variabel independen (diklat/bimtek penyusunan laporan keuangan) terhadap variabel dependen (kompetensi SDM yang menjadi peserta diklat tersebut).

6. Demikian pengujian secara parsial maupun secara simultan/bersama-sama pengaruh variabel independen (komitmen pimpinan instansi, kompetensi SDM, dan penggunaan aplikasi akuntansi) terhadap variabel dependen (keberhasilan penerapan akuntansi pemerintah berbasis akrual).

\section{HASIL DAN PEMBAHASAN}

\section{Gambaran Umum Responden}

Responden utama penelitian adalah para pegawai penatausahaan keuangan di lingkungan 44 unit satker Kota Bekasi, yang terlibat dalam penyusunan laporan keuangan pada instansinya. Tiap satker diberikan kuesioner sebanyak 3 eksemplar untuk Pimpinan satker, PPK-SKPD dan staf yang membantu PPK-SKPD, sehingga jumlah kuesioner yang didistribusikan sebanyak 132 eksemplar. Namun demikian tidak semua kuesioner dapat kembali. Berikut adalah perincian tingkat distribusi dan pengembalian kuesioner.

Tabel 4.1

Perincian sampel penelitian

\begin{tabular}{|l|c|}
\hline \multicolumn{1}{|c|}{ Keterangan } & Jumlah \\
\hline Kuesioner yang didistribusikan & 132 \\
\hline Kuesioner yang tidak kembali & 26 \\
\hline Kuesioner tidak terisi lengkap & 3 \\
\hline Kuesioner yang layak digunakan & 103 \\
\hline Respon rate & $80,30 \%$ \\
\hline
\end{tabular}

Sumber: Penyebaran dan pengembalian kuesioner

Apabila memakai rumus Slovin dengan galat pendugaan (d) sebesar $5 \%$, maka sampel yang masuk dan dapat dipakai untuk membuktikan hipotesis, cukup diwakili dengan 100 sampel, dengan perhitungan sebagai berikut:

$$
\begin{aligned}
\mathrm{n} & =\mathrm{N}:\left\{\mathrm{N} \cdot \mathrm{d}^{2}+1\right\} \\
& =132:\left\{1+132(0.05)^{2}\right\}=132: 1,33=99,25 \text { atau dibulatkan } 100 \text { kuesioner. }
\end{aligned}
$$


Dengan demikian sebanyak 103 kuesioner yang masuk dan layak digunakan, cukup mewakili/representative untuk digunakan membuktikan hipotesis penelitian ini.
Jumlah sampel dalam penelitian ini adalah sebanyak 103 pegawai dari beberapa SKPD. Penyajian data mengenai identitas responden untuk memberikan gambaran tentang keadaan diri dari pada responden, adalah sebagai berikut:

Tabel 4.2

Karakteristik identitas responden

\begin{tabular}{|c|c|c|}
\hline & \multicolumn{2}{|c|}{ Responden } \\
\hline & Jumlah & Persentase \\
\hline \multicolumn{3}{|l|}{ Jenis kelamin } \\
\hline Laki-laki & 41 & 39.8 \\
\hline Perempuan & 62 & 60.2 \\
\hline \multicolumn{3}{|l|}{ Umur } \\
\hline$<30$ th & 4 & 3.9 \\
\hline $31-45$ th & 44 & 42.7 \\
\hline$>46$ th & 55 & 53.4 \\
\hline \multicolumn{3}{|l|}{ Pendidikan } \\
\hline D3 & 7 & 6.8 \\
\hline S1 / D4 & 47 & 45.6 \\
\hline S2 / S3 & 49 & 47.6 \\
\hline \multicolumn{3}{|l|}{ Lama bekerja } \\
\hline$<6$ th & 6 & 5.8 \\
\hline $6-10$ th & 20 & 16.4 \\
\hline$>11$ th & 73 & 74.8 \\
\hline
\end{tabular}

Sumber : Data primer yang diolah, 2016

Berdasarkan jenis kelamin, pegawai perempuan menunjukkan memiliki jumlah yang lebih banyak dibanding pegawai lakilaki, yaitu: $60,2 \%$ dibanding $39,8 \%$. Berdasarkan kelompok umur responden yang terbanyak adalah yang berumur lebih dari 46 tahun yaitu sebanyak 53,4\%. Berdasarkan tingkat pendidikan pegawai SKPD didominasi oleh pendidikan S1/D4 yaitu sebanyak $47,6 \%$, sedangkan berdasarkan lama masa kerja, pegawai SKPD sebagian besar memiliki masa kerja lebih dari 11 tahun yaitu sebanyak $74,8 \%$.

\begin{abstract}
Analisis Data
Pengujian Validitas dan Reliabilitas Instrumen

Pengujian validitas dilakukan dengan menggunakan nilai corrected item total correlation, sedangkan pengujian reliabilitas menggunakan rumus Cronbach Alpha. Pengujian validitas dan reliabilitas selengkapnya dapat dilihat pada Tabel 4.3 berikut ini.
\end{abstract}

Tabel 4.3 Hasil Pengujian Validitas

\begin{tabular}{|clcccc|}
\hline No & \multicolumn{1}{c}{ Variabel / Indikator } & r hitung & r tabel & Keterangan & Alpha \\
\hline $\mathbf{1}$ & Komitmen Pimpinan & & & & $\mathbf{0 , 9 0 9}$ \\
& Indikator 1 & .689 & 0.300 & Valid & \\
& Indikator 2 & .676 & 0.300 & Valid &
\end{tabular}




\begin{tabular}{|c|c|c|c|c|c|}
\hline & Indikator 3 & .747 & 0.300 & Valid & \\
\hline & Indikator 4 & .798 & 0.300 & Valid & \\
\hline & Indikator 5 & .717 & 0.300 & Valid & \\
\hline & Indikator 6 & .761 & 0.300 & Valid & \\
\hline & Indikator 7 & .714 & 0.300 & Valid & \\
\hline \multirow[t]{18}{*}{2} & Diklat/ Bimtek & & & & 0,956 \\
\hline & Indikator 1 & 661 & 0.300 & Valid & \\
\hline & Indikator 2 & .716 & 0.300 & Valid & \\
\hline & Indikator 3 & .709 & 0.300 & Valid & \\
\hline & Indikator 4 & .729 & 0.300 & Valid & \\
\hline & Indikator 5 & .720 & 0.300 & Valid & \\
\hline & Indikator 6 & .839 & 0.300 & Valid & \\
\hline & Indikator 7 & .778 & 0.300 & Valid & \\
\hline & Indikator 8 & .816 & 0.300 & Valid & \\
\hline & Indikator 9 & .763 & 0.300 & Valid & \\
\hline & Indikator 10 & .651 & 0.300 & Valid & \\
\hline & Indikator 11 & .718 & 0.300 & Valid & \\
\hline & Indikator 12 & .769 & 0.300 & Valid & \\
\hline & Indikator 13 & .757 & 0.300 & Valid & \\
\hline & Indikator 14 & .827 & 0.300 & Valid & \\
\hline & Indikator 15 & .626 & 0.300 & Valid & \\
\hline & Indikator 16 & .684 & 0.300 & Valid & \\
\hline & Indikator 17 & .722 & 0.300 & Valid & \\
\hline \multirow[t]{11}{*}{3} & PPA & & & & 0,926 \\
\hline & Indikator 1 & 690 & 0.300 & Valid & \\
\hline & Indikator 2 & .655 & 0.300 & Valid & \\
\hline & Indikator 3 & .795 & 0.300 & Valid & \\
\hline & Indikator 4 & .716 & 0.300 & Valid & \\
\hline & Indikator 5 & .781 & 0.300 & Valid & \\
\hline & Indikator 6 & 689 & 0.300 & Valid & \\
\hline & Indikator 7 & .717 & 0.300 & Valid & \\
\hline & Indikator 8 & .700 & 0.300 & Valid & \\
\hline & Indikator 9 & .782 & 0.300 & Valid & \\
\hline & Indikator 10 & .659 & 0.300 & Valid & \\
\hline \multirow[t]{10}{*}{4} & Kompetensi & & & & 0,884 \\
\hline & Indikator 1 & .436 & 0.300 & Valid & \\
\hline & Indikator 2 & .572 & 0.300 & Valid & \\
\hline & Indikator 3 & .660 & 0.300 & Valid & \\
\hline & Indikator 4 & .593 & 0.300 & Valid & \\
\hline & Indikator 5 & .538 & 0.300 & Valid & \\
\hline & Indikator 6 & .578 & 0.300 & Valid & \\
\hline & Indikator 7 & .687 & 0.300 & Valid & \\
\hline & Indikator 8 & .575 & 0.300 & Valid & \\
\hline & Indikator 9 & .663 & 0.300 & Valid & \\
\hline
\end{tabular}

JIAFE (Jurnal Ilmiah Akuntansi Fakultas Ekonomi)

Volume 2 No. 2 Tahun 2016, Hal. 1-15 


\begin{tabular}{|lllll|} 
& Indikator 10 & .708 & 0.300 & Valid \\
& Indikator 11 & .670 & 0.300 & Valid \\
\hline $\mathbf{5}$ & Keberhasilan & & & \\
& Indikator 1 & .654 & 0.300 & Valid \\
& Indikator 2 & .624 & 0.300 & Valid \\
& Indikator 3 & .717 & 0.300 & Valid \\
& Indikator 4 & .756 & 0.300 & Valid \\
& Indikator 5 & .783 & 0.300 & Valid \\
& Indikator 6 & .680 & 0.300 & Valid \\
Indikator 7 & .577 & 0.300 & Valid \\
Indikator 8 & .705 & 0.300 & Valid \\
\hline
\end{tabular}

Sumber : Data primer yang diolah 2016

Tabel 4.3 menunjukkan bahwa semua indikator yang digunakan untuk mengukur variabel-variabel yang digunakan dalam penelitian ini mempunyai koefisien korelasi yang lebih besar dari 0,30. Nilai $r$ hitung disajikan pada Tabel 4.3. Dari hasil tersebut menunjukkan bahwa semua indikator tersebut adalah valid.

Hasil uji reliabilitas menunjukkan bahwa kedua variabel mempunyai koefisien alpha yang cukup besar yaitu diatas $\mathbf{0 , 6 0}$ sehingga dapat dikatakan semua konsep pengukur masing-masing variabel dari kuesioner adalah reliabel yang berarti bahwa kuesioner yang digunakan dalam penelitian ini merupakan

\section{Analisis Deskriptif}

Berdasarkan hasil penelitian yang telah dilakukan terhadap 103 responden staf dan pimpinan PPK-SKPD melalui penyebaran kuesioner. Karena masing-masing variabel terdiri lebih dari satu item kuesioner, maka untuk mendapatkan kecenderungan jawaban responden terhadap jawaban masing-masing variabel. Kecenderungan jawaban responden terhadap jawaban masing-masing variabel akan didasarkan pada nilai rata-rata skor jawaban yang selanjutnya akan dikategorikan pada rentang skor berikut ini: kuesioner yang handal.

Tabel 4.4

Deskripsi jawaban responden

\begin{tabular}{|lcrrrr|}
\hline & N & Minimum & Maximum & Mean & Std. Deviation \\
\hline Diklat/bimtek Penyusunan Lap Keu & 103 & 3.00 & 5.00 & 4.2239 & .43641 \\
Komitmen Pimpinan & 103 & 2.57 & 5.00 & 4.3467 & .47616 \\
Kompetensi SDM & 103 & 3.00 & 5.00 & 4.1801 & .40834 \\
Penggunaan Aplikasi Akuntansi & 103 & 2.90 & 5.00 & 4.1699 & .53042 \\
Keberhasilan Penerapan & 103 & 3.38 & 5.00 & 4.2682 & .42386 \\
\hline
\end{tabular}

Sumber : Data primer yang diolah 2016

Berdasarkan penilaian atas variabelvariabel: diklat/bimtek, komitmen pimpinan instansi, kompetensi SDM, dan penggunaan aplikasi akuntansi, maupun variabel keberhasilan penerapan akuntansi berbasis akrual menunjukkan rata-rata indeks skor sebesar 4,24. Kondisi demikian mencerminkan semua variabel yang digunakan dalam penelitian ini sudah sesuai. Nilai rata-rata sebesar 4,24 tersebut menunjukkan lebih besar dari nilai tengah skala ukuran 5 yaitu sebesar 3,0. Hal ini menunjukkan bahwa kelima variabel yang terkait dengan keberhasilan penerapan 
laporan keuangan pemerintah daerah berbasis akrual di Kota Bekasi sudah dinilai dengan baik dan sesuai.

\section{Analisis Jalur}

Pengujian hipotesis dalam penelitian ini dilakukan dengan menggunakan analisis jalur (path analisys). Model teoritis yang telah digambarkan pada diagram jalur sebelumnya akan dilakukan analisis berdasarkan data yang telah diperoleh. Metode analisis jalur dilakukan dengan menggunakan software AMOS.

\section{Uji Normalitas Data}

Setiap model jalur yang baik harus memenuhi asumsi normalitas. Untuk itu sebelum membahas pengujian hipotesis pada model penelitian, terlebih dahulu akan dilihat mengenai asumsi normalitas data. Pengujian normalitas dilakukan dengan mengamati nilai skewness data yang digunakan, apabila nilai CR pada skewness data berada pada rentang antara \pm 2.58 . Hasil pengujian normalitas data ditampilkan pada Tabel 4.10 berikut:

Tabel 4.10

Uji Normalitas Data

\begin{tabular}{|l|ccrrrr|}
\hline \multicolumn{1}{|c|}{ Variable } & min & max & skew & c.r. & kurtosis & \multicolumn{1}{c|}{ c.r. } \\
\hline Diklat & 3.000 & 5.000 & .231 & .957 & .005 & .011 \\
PAA & 2.900 & 5.000 & .004 & .015 & -.552 & -1.144 \\
Kompetensi & 3.000 & 5.000 & .347 & 1.439 & .126 & .262 \\
Komitmen & 2.571 & 5.000 & -.498 & -2.064 & .653 & 1.352 \\
Keberhasilan & 3.375 & 5.000 & .540 & 2.237 & -.683 & -1.414 \\
Multivariate & & & & & 8.355 & 5.067 \\
\hline
\end{tabular}

Sumber: Data primer yang diolah

Evaluasi normalitas dilakukan dengan menggunakan kriteria critical ratio skewness value dan kurtosis value, yang hasilnya menunjukkan bahwa semua variabel sudah terdistribusi normal secara univariate. Secara multivariate juga sudah menunjukkan terdistribusi normal dimana nilai kurtosis memiliki CR sebesar 5,067<8.00.

\section{Pengujian Hipotesis}

Analisis hasil pengolahan data pada tahap model jalur dilakukan dengan melakukan uji kesesuaian dan uji statistik. Hasil pengolahan data untuk analisis model jalur ditampilkan pada tabel 4.11 sebagai berikut:

Tabel 4.11

Regression Weight Structural Equational

\begin{tabular}{|lll|cccc|}
\hline & & & Estimate & S.E. & C.R. & P \\
\hline Kompetensi & $<---$ & Diklat/Bimtek & 0.728 & 0.058 & 12.52 & $* * *$ \\
Keberhasilan & $<---$ & Komitmen & 0.264 & 0.062 & 4.243 & $* * *$ \\
Keberhasilan & $<---$ & Kompetensi & 0.438 & 0.073 & 6.039 & $* * *$ \\
Keberhasilan & $<---$ & PAA & 0.195 & 0.057 & 3.449 & $* * *$ \\
\hline
\end{tabular}

Sumber : Data primer yang diolah

Model persamaan regresi yang dapat dituliskan dari hasil tersebut dalam bentuk persamaan regresi adalah sebagai berikut : 


\section{Kompetensi $=0,728$ Diklat + e1 \\ Keberhasilan = 0,264 Komitmen + 0,438 Kompetensi + 0,195 PAA + e2}

Persamaan regresi tersebut menjelaskan bahwa koefisien regresi variabel diklat/bimtek, komitmen pimpinan, kompetensi SDM, serta penggunaan aplikasi akuntansi memiliki arah positif. Hal ini menunjukkan bahwa variabel diklat/bimtek, komitmen pimpinan dan penggunaan aplikasi akuntansi mempunyai potensi untuk meningkakan keberhasilan penerapan akuntansi berbasis akrual pada Pemerintah Daerah Kota Bekasi.

\section{Pengaruh Diklat/Bimtek terhadap Kompetensi SDM}

Hasil pengujian diperoleh nilai CR untuk variabel diklat/bimtek terhadap kompetensi SDM menunjukkan nilai $C R=12,52$ dengan nilai signifikansi sebesar $0,000<0,05$. Dengan demikian diperoleh bahwa hipotesis yang menyatakan bahwa pendidikan dan pelatihan/ bimbingan teknis memiliki pengaruh positif yang signifikan terhadap peningkatan kompetensi pegawai/SDM dapat diterima.

\section{Pengaruh Komitmen Pimpinan terhadap Keberhasilan}

Hasil pengujian diperoleh nilai CR untuk variabel komitmen pimpinan terhadap keberhasilan penerapan akuntansi berbasis akrual menunjukkan nilai $\mathrm{CR}=4,243$ dengan nilai signifikansi sebesar $0,000<0,05$. Dengan demikian diperoleh bahwa hipotesis yang menyatakan bahwa komitmen pimpinan memiliki pengaruh positif yang signifikan terhadap keberhasilan penerapan akuntansi berbasis akrual pemerintah daerah dapat diterima.

\section{Pengaruh Kompetensi SDM terhadap Keberhasilan}

Hasil pengujian diperoleh nilai CR untuk variabel kompetensi SDM terhadap keberhasilan penerapan akuntansi berbasis akrual menunjukkan nilai $\mathrm{CR}=6,039$ dengan nilai signifikansi sebesar $0,000<0,05$. Dengan demikian diperoleh bahwa hipotesis yang menyatakan bahwa kompetensi SDM/pegawai memiliki pengaruh positif yang signifikan terhadap keberhasilan penerapan akuntansi berbasis akrual pemerintah daerah dapat diterima.

\section{Pengaruh Penggunaan Aplikasi Akuntansi terhadap Keberhasilan}

Hasil pengujian diperoleh nilai CR untuk variabel penggunaan aplikasi akuntansi terhadap keberhasilan penerapan akuntansi berbasis akrual menunjukkan nilai $\mathrm{CR}=3,449$ dengan nilai signifikansi sebesar 0,000<0,05. Dengan demikian diperoleh bahwa hipotesis yang menyatakan bahwa Penggunaan Aplikasi Akuntansi (PAA) memiliki pengaruh positif yang signifikan terhadap keberhasilan penerapan akuntansi berbasis akrual pemerintah daerah dapat diterima.

\section{Koefisien Determinasi}

Koefisien determinasi ini digunakan untuk mengetahui seberapa besar pengaruh variabel-variabel bebas memiliki pengaruh terhadap variabel terikatnya.

Tabel 4.12

Koefisien determinasi

\begin{tabular}{|l|c|}
\hline & Estimate \\
\hline Kompetensi SDM & .606 \\
Keberhasilan Penerapan & .643 \\
\hline
\end{tabular}

Hasil perhitungan regresi dapat sebesar 0,606. Hasil ini menunjukkan bahwa diketahui bahwa koefisien determinasi pada sebesar 60,6\% kompetensi SDM/pegawai variabel kompetensi SDM diketahui koefisien dapat meningkat seiring dengan semakin 
baiknya diklat/bimtek penyusunan laporan keuangan dengan sistem SIMDA yang diberikan oleh BPKP, dan sisanya sebesar $39,4 \%$ kompetensi dapat dipengaruhi variabel lain.

Hasil perhitungan regresi dapat diketahui bahwa koefisien determinasi pada variabel keberhasilan diketahui koefisien sebesar 0,643. Hasil ini menunjukkan bahwa sebesar 64,3\% keberhasilan penerapan akuntansi berbasis akrual dapat meningkat seiring dengan semakin baiknya: kompetensi SDM, komitmen pimpinan dan penggunaan aplikasi akuntansi oleh pegawai, dan sisanya sebesar $35,7 \%$ keberhasilan dapat dipengaruhi variabel lain.

\section{Pembahasan}

Dari hasil analisis regresi linier sebagaimana yang telah dikemukakan di atas telah didapat angka-angka statistik yang dapat memberikan petunjuk atau gambaran tentang pengaruh variabel diklat/bimtek yang dilakukan terhadap variabel kompetensi pegawai pemerintah daerah, dan sekaligus menunjukkan bahwa hipotesis yang diajukan untuk penelitian ini dapat diterima. Berdasarkan hasil analisis statistik tersebut memberikan bukti empiris dimana pendidikan dan pelatihan (diklat) atau bimbingan teknis (bimtek) khususnya dalam bidang penyusunan laporan keuangan pemerintah daerah berbasis akrual dengan SIMDA, memiliki hubungan fungsional dan memiliki pengaruh positif dan signifikan terhadap peningkatan kompetensi SDM/pegawai.

Hasil analisis regresi linier tersebut memberikan kesimpulan bahwa diklat/bimtek mempunyai hubungan fungsional/pengaruh positif dan signifikan terhadap peningkatan kompetensi SDM. Dengan kata lain dapatlah dinyatakan bahwa diklat/bimtek dapat menyebabkan peningkatan secara signifikan kompetensi SDM yang bertugas menyusun laporan keuangan pemerintah daerah. Hal ini berarti bahwa makin tinggi atau makin banyak diklat/bimtek yang diikuti baik oleh pimpinan maupun staf PPK-SKPD, maka akan semakin meningkatkan kompetensi para pimpinan maupun staf PPK-SKPD tersebut.
Pengaruh diklat/bimtek terhadap kompetensi kerja aparatur tersebut adalah nyata atau signifikan, sebagaimana ditunjukkan dengan hasil pengujian signifikansi. Kondisi ini dapat memberikan petunjuk bahwa diklat/ bimtek merupakan faktor dominan atau penentu utama terhadap peningkatan kompetensi staf maupun pimpinan PPK-SKPD. Dimana semakin banyak atau semakin baik pelaksanaan diklat/bimtek kepada staf maupun pimpinan PPK-SKPD, maka akan semakin meningkatkan kompetensi staf maupun pimpinan PPK-SKPD tersebut. $\mathrm{Hal}$ ini menunjukkan pula bahwa diklat/bimtek dapat digunakan untuk memprediksi perkembangan atau peningkatan kompetensi staf maupun pimpinan PPK-SKPD.

Pendidikan dan pelatihan (diklat) atau bimbingan teknis (bimtek) yang diberikan kepada staf maupun pimpinan PPK-SKPD nampaknya menjadi usaha mengurangi atau menghilangkan terjadinya kesenjangan antara kemampuan staf/pimpinan PPK-SKPD dengan yang dikehendaki organisasi dan profesi. Usaha tersebut dilakukan melalui peningkatan kemampuan kerja yang dimiliki staf/pimpinan PPK-SKPD dengan cara menambah pengetahuan dan keterampilan serta merubah sikap. Bagi staf/pimpinan PPK-SKPD di lingkungan Pemerintah Kota Bekasi, diklat/bimtek merupakan upaya yang dilakukan untuk meningkatkan kepribadian, pengetahuan dan kemampuan sesuai dengan tuntutan persyaratan jabatan dan pekerjaan sebagai auditor.

Diklat/bimtek kepada staf maupun pimpinan PPK-SKPD Kota Bekasi merupakan proses transformasi kompetensi sumber daya manusia yang menyentuh empat dimensi utama, yaitu: dimensi spritual, intelektual, mental, dan fisik yang terarah pada perubahanperubahan kualitas dari keempat dimensi sumber daya manusia aparatur tersebut (Sedarmayanti, 2009). PP Nomor 101 Tahun 2000 juga menyebutkan bahwa sasaran pendidikan dan pelatihan jabatan PNS adalah terwujudnya PNS yang memiliki kompetensi (pengetahuan, keterampilan, dan sikap 
perilaku) yang sesuai dengan persyaratan tugas jabatan atau pekerjaan masing-masing.

Hasil penelitian ini memberikan implikasi penting yaitu perlunya meningkatkan kerjasama antara Pemerintah Daerah kota Bekasi dengan BPKP, khususnya kerjasama dalam penyelengaraan diklat/bimtek teknis substansi di bidang penyusunan laporan keuangan pemerintah daerah, sehingga mereka lebih memiliki kompetensi kerja yang tinggi atau memadai dalam melaksanakan tugas dan jabatannya.

\section{PENUTUP}

\section{Kesimpulan}

Berdasarkan hasil penelitian ini sebagaimana telah diuraikan dan dibahas sebelumnya, maka dapatlah ditarik kesimpulan sebagai berikut :

1. Pendidikan dan Pelatihan/Bimbingan Teknis (Diklat/Bimtek) laporan keuangan kepada para pegawai SKPD di lingkungan Kota Bekasi memiliki pengaruh positif dan signifikan terhadap peningkatan kompetensi SDM.

2. Komitmen pimpinan instansi di lingkungan Kota Bekasi memiliki pengaruh positif dan signifikan terhadap keberhasilan penerapan laporan keuangan pemerintah daerah berbasis akrual.

3. Kompetensi SDM pada SKPD-SKPD di lingkungan Kota Bekasi memiliki pengaruh positif dan signifikan terhadap keberhasilan penerapan laporan keuangan pemerintah daerah berbasis akrual.

4. Penggunaan aplikasi akuntansi memiliki pengaruh positif dan signifikan terhadap keberhasilan penerapan laporan keuangan pemerintah daerah berbasis akrual.

\section{Saran}

Mendasari kepada hasil penelitian ini maka dapat dikemukakan beberapa saran sebagai berikut:
1. Pendidikan dan Pelatihan (Diklat) maupun Bimbingan Teknis (Bimtek) bagi para staf/pimpinan PPK-SKPD Kota Bekasi perlu ditingkatkan terutama diklat teknis subtansi dalam penyusunan laporan keuangan. Namun demikian implikasinya bahwa alokasi anggaran untuk program diklat/bimtek perlu ditingkatkan.

2. Program diklat/bimtek bagi para staf/pimpinan PPK-SKPD harus sepenuhnya mengacu pada prinsip kesesuaian antara jenjang diklat dengan kebutuhan obyektif dan riil pelaksanaan tugas pada semua level organisasi. Untuk itu penyelenggaraan diklat harus didasarkan pada deskripsi pekerjaan (job description) dan analisis jabatan (job analysis) yang akurat dan tepat.

3. Perlunya meningkatkan kerjasama antara Pemerintah Kota Bekasi dengan BPKP di masa kini dan mendatang dalam rangka penyusunan laporan keuangan dengan basis akrual. Sehingga tidak hanya di tahun anggaran 2016 , untuk tahun anggaran mendatang, laporan keuangan Pemerintah Daerah Bekasi mendapatkan opini wajar tanpa pengecualian dari Badan Pemeriksa Keuangan.

\section{DAFTAR PUSTAKA}

Metode-akuntansi-kas-basis-akrual-basis. http://dhycana.wordpress.com L2008/11/21> accessed 15/01/2010.

Accounting Study Guide <http://accountinginfo.com/study/accru al-101.htm > accessed 15/01/2010.

Forum Konsultasi SAP <http://www.ksap.org/konsultasi.php> accessed 15/12/2009.

Implementasi SAP Berbasis Akrual, Strategi dan Pentahapannya di Indonesia. <http://www.ksap.org/liputan4.php> accessed 06/01/2010.

Five Countries Pionneering Accrual Budgeting and Accounting in Central Government $<$.http//www.intosaijournal.org/technica 
larticles/technicaljan04b.html> accessed 15/01/2010.

International Market Research-ADB GOVT ACCOUNTING PROJ

$<$ http://74.6.146.127/search/cache?ei=U TF-8\&p=Reseach+of+accrual $>$ accessed 21/02/2010.

Pemda DKI Hanya Diawasi 20 Auditor Keuangan

$<$ http://www.detikfinance.com/read/20 08/08/07/131508/984572/4/ars...> accessed 23/02/2010.

Badan Pemeriksa Keuangan - RI, Juni 2009, Laporan Hasil Pemeriksaan atas LKPP Tahun Anggaran 2008, Jakarta.

Maret 2009, Ikhtisar Hasil Pemeriksaan Semester II Tahun 2008, Jakarta.

Deddi Nordiawan dkk., 2007, Akuntansi Pemerintahan, Jakarta, Penerbit Salemba Empat.

Departemen Pendidikan Nasional, 2011, Kamus Besar Bahasa Indonesia, Edisi Ketiga, Jakarta: Balai Pustaka.

DPR RI, 2004, Undang Undang nomor 17 Tahun 2003 tentang Keuangan Negara.

DPR RI, 2004, Undang Undang nomor 1 Tahun 2004 tentang Perbendaharaan Negara.

DPR RI, 2004, Undang Undang nomor 10 Tahun 2004 tentang Pembentukan Peraturan Perundangundangan.

Indra Bastian, 2006, Sistem Akuntansi Sektor Publik, Jakarta, Penerbit Salemba Empat.

Kelsen, Hans, dalam Maria Indriadi Soeprapto, 1998 : 2, dalam Suryaningsih, Tinjauan terhadap Pengembangan Wilayah Perumahan dan Pemukiman dalam Rangka Pembangunan Berkelanjutan. Web: wisnuwardhana.ac.id/fh/index, Februari 208.

Komite Standar Akuntansi Pemerintahan, 2005, Standar Akuntansi Pemerintahan, (dalam Peraturan Pemerintah Nomor : 24 Tahun 2005), Jakarta.

2006, Bahan Bahasan Untuk Limited Hearing, Jakarta.
2009, Rancangan Peraturan Pemerintah tentang SAP Berbasis Akrual.

Mardiasmo, 2002, Akuntansi Sektor Publik, Yogyakarta, penerbit Andi.

Muindro Renyowijoyo, 2008, Akuntansi Sektor Publik - Organisasi Non Laba, Jakarta, Penerbit Mitra Wacana media.

Moh. Nazir, 1988, Metode Penelitian, Penerbit Ghalia Indonesia, Jakarta.

Undang-Undang Nomor 15 tahun 2004, tentang Pemeriksaan atas Pengelolaan dan Pertanggungjawaban Keuangan Negara, Bandung, Penerbit Fokusmedia.

Undang-Undang Nomor 33 tahun 2004, tentang Perimbangan Keuangan Antara Pusat dan Pemerintah Daerah, Bandung, Penerbit "Citra Umbara".

Keputusan Presiden Nomor 42 tahun 2002, tentang Pedoman Pelaksanaan Anggaran Pendapatan dan Belanja Negara, Jakarta, Penerbit CV. Tamita Utama.

Keputusan Presiden Nomor 80 tahun 2003, tentang Pedoman Pelaksanaan Pengadaan Barang/Jasa Pemerintah, Bandung, Penerbit Fokus media.

Luthans, Fred, 2006, Perilaku Organisasi, Edisi 10, Alih Bahasa oleh Vivin Andika Yuwono, ANDI,Yogyakarta.

Peraturan Menteri Negara Pendayagunaan Aparatur Negara Nomor: PER/22/M.PAN/ 4/2006 tentang Jabatan Fungsional Widyaiswara dan Angka Kreditnya, Jakarta, LAN-RI.

Peraturan Kepala Lembaga Administrasi Negara Nomor : 3 Tahun 2006 tentang Pedoman Pelaksanaan Orasi Ilmiah Widyaiswara, Jakarta, LAN-RI.

Stoner, A.F., 2002, Fundamental of Financial Managing, Carvalis OR: Authors Academic Publishing, USA, Cetakan Pertama, Alih Bahasa oleh Wandi S. Brata, Gramedia Pustaka Umum, Jakarta.

Susilo,W, 2002, Audit Sumber Daya Manusia, Penerbit Gema Amini, Jakarta. 